dratedo

JURNAL ILMIAH SOSIAL KEAGAMAAN
ALFUAD JOURNAL, 4 (1), 2020, (56-66)

(E-ISSN 2714-7606 P-ISSN 2614-4786 )

Available online at

http://ecampus.iainbatusangkar.ac.id/ojs/index.php/alfuad

\title{
PENERAPAN TEKNIK MODIFIKASI PERILAKU DALAM MENINGKATKAN SEMANGAT BELAJAR ANAK SELAMA "STAY AT HOME"
}

\author{
Aufa Melia Mareta \\ Universitas Islam Negeri Imam Bonjol \\ Padang, \\ Indonesia. \\ E-mail:jackbrownfha@gmail.com
}

\begin{abstract}
The spirit of learning in children during COVID-19 is a challenge that is present for teachers and parents. This paper aims to provide a brief description of how behavior modification techniques namely fading, economic tokens, and shaping provide solutions in shaping, maintaining, and enhancing children's enthusiasm for learning during "stay at home". The author uses descriptive methods in analyzing this paper. The results of this paper are that the three techniques (fading, economic tokens, and shaping) are considered effective in shaping the target behavior, that is, children's enthusiasm for learning during the pandemic.
\end{abstract}

Keywords: Behaviour Modification, Spirit of Study, Stay at Home

\section{PENDAHULUAN}

Belajar dan mengajar merupakan dua proses yang saling berkesinambungan dan tidak bisa dipisahkan satu sama lainnya. Proses belajar dan mengajar tersebut tertuang dalam sarana pendidikan berbasis sekolah. Di Indonesia, termaktup jelas dalam UUD Negara kesatuan Republik Indonesia 1945 Pasal 31 bahwa setiap anak bangsa wajib mendapatkan pendidikan dan pemerintah wajib membayarkannya. Namun, beberapa waktu terakhir, hampir seluruh anak di dunia terhalang dalam proses belajar dan mendapatkan pengajaran dari instansi-instansi entah itu sekolah atau lembaga penyedia tenaga pengajar lainnya. Semua berawal semenjak sebuah virus yang baru-baru ini popular dengan sebutan COVID-19 (Coronavirus Disease) menjadi momok menakutkan bagi seluruh kalangan seantero dunia. UNESCO menyatakan bahwa hampir 300 juta siswa di dunia terganggu sekolah dan terancam masa depannya dikarenakan COVID-19.

COVID-19 pertama kali muncul pada sebuah kota bernama Wuhan di salah satu provinsi, Hubei di Tiongkok pada akhir 2019 tahun lalu. Di Indonesia sendiri, COVID-19 mulai menjadi perbincangan hangat saat 2 orang warga Depok dinyatakan positif pada pertengan Februari lalu dan sampai sekarang angka positif terus membentuk grafik naik. Dilansir dari CNN Indonesia pada 13 Mei 2020, jumlah kasus positif COVID-19 di Indonesia sejak diumumkan pertama kali berjumlah 15.438 kasus setelah tambahan 689 kasus positif 
per Rabu (13/5). Dengan angka yang setiap harinya bertambah, membuat pemerintah menerapkan kebijakan Stay at Home (SFH), Work from Home (WFH), dan Learn from Home (WFH). Sehingga semua kegiatan yang berbasis tatap muka dialihkan menjadi daring. Banyak positif negatif yang harus dihadapi para siswa selama pandemi berlangsung. Namun, yang paling menjadi tantangan sejak awal diberlakukannya kebijakan diatas adalah semangat belajar para siswa khususnya siswa Sekolah Dasar yang masih terkategori anak-anak. Terlebih lagi barubaru ini sudah dikeluarkannya pernyataan bahwa pola pembelajaran seperti ini akan berlangsung sampai akhir tahun 2020. Awalnya mungkin para siswa merasa senang saat diberikan libur sekolah beberapa minggu sebelum akhirnya diliburkan sampai waktu yang belum ditentukan. Banyak hal yang menyebabkan perilaku semangat belajar para siswa menjadi deficit ditengah-tengah pandemik. Misalnya, kurangnya motivasi atau dorongan dari diri sendiri atau pun dorongan dari luar, fasilitas yang tidak memadai, dan tenaga pengajar yang sulit menerapkan metode belajar di rumah. Namun, poin utama yang akan dibahas pada tulisan ini adalah bagaimana teknik modifikasi perilaku meningkatkan motivasi sehingga melahirkan semangat belajar untuk para siswa yang melakukan daring di rumah selama pandemi berlangsung.

\section{METODE}

Pendekatan yang digunakan dalam penulisan paper ini menggunakan pendekatan kulaitatif dengan pembahasan dilakukan melalui analisis deskriptif. Data yang digunakan bersumber dari buku, jurnal, dan observasi tidak langsung ke website CNN Indonesia dan beberap channel yutube pemeberitaan Indonesia seperti KOMPAS TV dan NET TV. Analisis dilakukan berupa analisis deskriptif, dengan memaknai dan menghubungkan setiap literatur yang berhasil didapat.

\section{HASIL DAN PEMBAHASAN}

Dalam proses belajar dan mengajar, tenaga pendidik dan yang dididik dijembatani oleh sebuah rasa agar keduanya saling terhubung. Rasa tersebut adalah semangat, entah itu semangat dalam belajar atau pun semangat dalam mengajar. Rasa semangat tersebut tertuang dalam bentuk motivasi atau dorongan yang membuat siswa maupun guru bisa samasama menjalankan tanggung jawabnya masing-masing. Menurut Wardani (2016), motivasi dapat didefinisikan sebagai proses psikologi yang menghasilkan suatu intensitas, arah dan ketekunan individual dalam usaha untuk mencapai suatu tujuan. Pada asasnya motivasi merupakan 
semangat dalam yang paling kuat untuk mencapai sesuatu, ini juga merupakan suatu keinginan yang paling kuat untuk mendapat kejayaan dan kecemerlangan, motivasi merujuk pada desakan hati serta naluri yang menggerakkan individu untuk membuat tindakan seperti rangsangan, keperluan, kehendak, dan kemahuan yang dikehendaki dalam hidup (Akmam, 2005). Dalam kegiatan belajar, motivasi ini diperlukan untuk mendapatkan hasil belajar yang optimal, makin tepat motivasinya maka makin tepat pula keberhasilan pembelajarannya. Motivasi berfungsi sebagai pendorong, pengarah, serta penggerak seseorang untuk mencapai tujuan. Setiap motivasi dan perilaku pada setiap individu akan menghasilkan peristiwa yang berbeda pula. Setiap individu memiliki keinginan dan dorongan untuk melakukan suatu tindakan yang mengarah pada pencapaian tujuan yang diinginkan.

Berikut fungsi-fungsi motivasi dalam pembelajaran untuk mendapatkan hasil belajar yang optimal diantaranya (a) Mendorong timbulnya tingkah laku, misalnya belajar (b) Mengarahkan agar perbuatan-perbuatan yang di lakukan dapat mencapai tujuan (c) Untuk menggerakkan tingkah laku seseorang.

Dalam membangkitkan, mempertahankan, ataupun meningkatkan semangat belajar siswa, diperlukan motivasi yang kuat untuk bisa mewujudkan tujuan dan keinginannya. Hal ini dapat dibuktikan dari beberapa jurnal penelitian bahwa teknik modifikasi perilaku fading, shaping, dan token ekonomi dapat digunakan dalam membangkitkan, mempertahankan, atau pun meningkatkan semangat belajar siswa. Namun keberhasilan teknik tersebut tidak serta-merta karena kemantapan teori melainkan juga dipengaruhi oleh pribadi individu terkait dan dukungan sosial juga sangat diperhitungkan untuk menjamin keberhasilan teknik yang digunakan. Maka dengan meningkatkan motivasi belajar siswa, diharapkan juga dapat sekaligus membangkitkan semangat belajar para siswa selama stay at home.

\section{Teknik Modifikasi Perilaku dan Panduan Pelaksanaan}

\section{Fading}

Fading merupakan salah satu teknik modifikasi perilaku dengan mengurangi ketergantungan terhadap prompt atau bantuan melalui prosedur tertentu. Fading secara bertahap menghapus atau mengubah prompt sehingga menjadi lebih dan lebih seperti anteseden normal untuk perilaku (Danforth, 2005; Deitz \& Malone, 1985; Demchak, 1990; Rilling, 1977 dalam Sarafino, 2012). Menurut Martin \& Joseph Pear (2015), fading merupakan perubahan 
bertahap atas percobaan stimulus anteseden yang mengontrol respon sehingga akhirnya stimulus diuabah menjadi sebuah perilaku yang diinginkan.

Dalam penerapannya, pada situasi pandemi saat ini, fading bisa dijadikan salah satu metode yang digunakan dalam membentuk sebuah perilaku terhadap anak. Seperti yang dilansir oleh official NET News di akun yutube-nya pada 17 Maret 2020, salah seorang orang tua menyebutkan bahwa selama diberlakukannya learning from home, anak lebih cenderung mengandalkan orang tua. Karena anak berpikir bahwa segalanya akan lebih mudah dengan sentuhan tangan orang tua. Selain itu, orang tua yang juga dituntut untuk work from home juga tidak punya alas an untuk melakukan kegiatan di luar rumah. Hal tersebut merupakan pemicu hilangnya semangat belajar terhadap anak karena memiliki anggapan seperti itu. Namun, sebagai orang tua juga harus bijak dalam memberikan prompt atau bantuan terhadap anak saat mengerjakan tugas yang diberikan guru melalui beberapa platform yang bisa diakses pada ponsel pintar. Dengan memberikan kesempatan untuk menyelesaikan tugas kepada anak, secara tidak langsung orang tua juga menanamkan rasa bertanggung jawab kepada anak.
Ketika anak terus-terusan meminta bantuan kepada orang tua dalam memecahkan soal-soal tugas yang diberikan guru, orang tua dituntut untuk tidak membuat anak tergantung atas bantuannya. Memberikan kesempatan kepada anak berani mandiri adalah keinginan mayoritas orang tua. Sehingga dengan menerapkan fading mungkin bisa menjadi salah satu solusi yang dapat dilakukan orang tua. Pertama, orang tua harus bisa membedakan antara benar-benar butuh bantuan dan mana yang hanya purapura membutuhkan bantuan. Jika anak benar-benar membutuhkan bantuan maka orang tua bisa melakukan tahap kedua, yaitu orang tua bisa memberikan stimulus berupa pertanyaan yang memancing pengetahuan anak sehingga akan terjadi komunikasi dua arah antara orang tua dan anak. Dengan kata lain, orang tua memberikan bantuan verbal kepada anak. Artinya, orang tua tidak terkesan mengambil alih tugas yang diperuntukkan kepada anak. Kemudian pada tahapan ketiga, anak bisa diberikan bantuan berupa modelling seperti mencontohkan beberapa penjelasan gambar dengan bantuan gerakan tubuh secara langsung. Sehingga, dengan hadirnya prompt atau bantuan secara fisik akan membuat bantuan verbal menjadi stimulus diskriminasi yang kehadirannya bisa dikontrol. Pada tahapan keempat, anak dapat diminta menuliskan 
atau menjelaskan atau pun menjawab soalsoal dengan tidak menerima bantuan secara verbal maupun secara fisik. Dengan begitu, jika perilaku yang diharapkan seperti anak bisa mengerjakan tugas dengan tidak sepenuhnya bergantung pada orang tua, teknik fading berhasil digunakan dalam modifikasi perilaku. Dengan membuat anak bisa dan berani menyelesaikan persoalan sekolah tanpa harus bergantung kepada orang tua merupakan salah bentuk yang menunjukkan semangat anak dalam belajar di rumah selama pandemi berlangsung.

Tahapan fading: (1) Stimulus (tugas) + prompt (bantuan verbal) $\rightarrow$ Anak mengerjakan tugas. (2) Stimulus (tugas) + prompt (bantuan fisik) $\rightarrow$ Anak mengerjakan tugas. (3) Stimulus (tugas) + no prompt $\rightarrow$ Anak mampu mengerjakan tugas.

Dengan diterapkannya teknik fading dari orang tua kepada anak, maka diharapkan anak tetap bisa mengerjakan tugas-tugas sekolah tanpa harus bergantung sepenuhnya kepada orang tua. Penelitian Parmawati, dkk (2015) yang dirilis oleh PSIBERNETIKA menyebukan bahwa teknik fading dinilai efektif dalam meningkatkan kosa kata anak tuna rungu. Dengan kata lain, ketika anak disabilitas berhasil mencapai perilaku target dengan teknik ini, maka juga akan sangat mudah diterapkan kepada anak normal yang tidak bersekolah di SLB layaknya tuna rungu. Efektivitas penerapan fading dalam penerapannya memodifikasi perilaku pada anak juga telah dibuktikan dalam penelitian Larassati \& Hartiani (2018) yang dirilis oleh Jurnal Psikologi Teori dan Terapan.

\section{Token Ekonomi}

Selama diberlakukannya slogan "di rumah aja" tidak hanya sektor perekonomian yang merosot, melainkan banyak sector pendidikan yang pada akhirnya harus dialihkan ke rumah masingmasing. Hal ini menjadi tantangan tersendiri untuk para guru dan siswa untuk tetap efektif dalam melakukan proses pembelajaran walaupun tidak dilakukan di sekolah atau tatap muka secara langsung. Dilansir dari KompasTV pada 5 Mai 2020, salah satu kendala dalam pelaksanaan pembelajaran daring adalah guru sulit menerapkan metode belajar di rumah sehingga akan berdampak pada anak didik. Misalnya pada mata pelajaran pendidikan kewarganegaraan, salah satu penilaian utama oleh guru adalah sikap dan perilaku anak. Namun, para guru akan kesulitan melihat bagaimana sikap dan perilaku anak selama pembelajaran dilakukan secara daring. Tidak hanya itu, banyak guru matematika yang juga bernasip sama dengan guru pendidikan kewarganegaraan. Seperti yang sama-sama diketahui, 
matematika bukan ilmu yang bisa dihapal layaknya Ilmu Pengetahuan Sosial, lebih dari itu, matematika membutuhkan penjelasan dan latihan soal sehingga tidak ada cara yang lebih efektif dalam menyampaikan materi selain tatap muka secara langsung. Ketidaksanggupan dan kesulitan guru dalam menyampaikan materi kepada anak juga merupakan salah satu pemicu yang dapat melemahkan semangat anak dalam belajar. Bagaimana mungkin tanpa bantuan penjelasan guru matematika anak bisa menjabarkan perkalian dengan baik. Maka dari itu, orang tua lagi-lagi berperan sangat signifikan untuk membantu anak dalam memahami tugas-tugas sekolah. Tentu saja masih dalam batas sewajarnya.

Dengan kendala pembelajaran seperti pola diatas, maka guru-guru dituntut untuk lebih mengedepankan proses dibandingkan hasil. Misalnya anak dinilai melalui kedisiplinan dalam mengikuti kelas di platform yang sudah disepakati. Keterlambatan anak dalam mengikuti kelas mungkin bisa menjadi salah satu indikator penilaian yang bisa dilakukan oleh para guru. Kedisiplinan anak dalam mengumpulkan dan mengerjakan tugas yang diberikan, bukan hanya sebatas penilaian akhir dari hasil tugas yang dikerjakan. Dengan begitu, setidaknya anak masih memiliki semangat sampai akhir dalam menyelesaikan tugas karena masih memiliki harapan bahwa tugasnya akan tetap dinilai jika diserahkan tepat waktu walau kebenaran dalam hasil tugasnya sangat diragukan. Tidak hanya sampai disitu, guru juga harus lebih cerdas dalam mempertahankan semangat dan motivasi anak didiknya. Salah satu teknik modifikasi perilaku yang dapat dilakukan adalah dengan menerapkan token ekonomi.

Token ekonomi sering digunakan dalam pendidikan dan dalam program modifikasi perilaku. Menurut Martin \& Joseph Pear (2015), token ekonomi merupakan program perilaku di mana individu dapat memperoleh token atau penanda untuk berbagai perilaku yang diinginkan dan dapat menukar token yang diperoleh dengan penguat cadangan berupa benda, makanan, dan sejenisnya yang merupakan keinginan dari individu terkait. Token ekonomi biasanya dapat berbentuk ceklis, bintang, emotikon senyum, dan sejenisnya. Pada masyarakat modern saat ini, token ekonomi dapat dijumpai seperti orang bekerja banting tulang untuk mendapatkan upah berupa uang yang nantinya dapat ditukarkan menjadi kebutuhan pokok dan kebutuhan lainnya. Penerapan token ekonomi pada anak dengan tujuan meningktakan semangat dan membeangkitkan motivasi anak dapat dilakukan oleh guru dengan bantuan orang tua sebagai berikut: (1) Penilaian dilakukan dengan menilai kedisiplinan 
anak dalam mengumpulkan tugas di platform diskusi online. Setiap anak yang mengumpulkan tugas dengan tepat waktu akan mendapatkan 10 emotikon senyuman dan akan terus berkurang jika anak mengumpulkan tugas semakin lama. (2) Tugas diberikan secara berkala dengan intensitas berbeda-beda sesuai kemampuan dan kesanggupan anak. Jika anak menyelesaikan tugas diluar waktu yang ditentukan atau dengan kata lain anak mengumpulkan tugas sebelum deadline, maka anak mendapatkan satu emotikon bintang. (3) Pada tahapan terakhir, semua emotikon senyum dan emotikon bintang dihitung dan dikalkulasikan. Dengan begitu, anak yang mendapatkan skor tertinggi dalam mengumpulkan emotikon senyum dan bintang berhak menukarkannya kepada guru atau orang tua dengan benda, makanan atau semacam keinginan anak yang harus diwujudkan oleh guru ataupun orang tua. Dengan menukarkan skor pendapatan emotikon oleh anak merupakan salah satu bentuk reinforcement atau penguatan yang dilakukan agar diharapkan terjadinya perilaku berulang.

Skema penerapan Token ekonomi: (1) Tugas + kedisiplinan $\rightarrow$ Token. (2) Tugas bertambah + kedisiplinan $\rightarrow$ Token. (3) Token yang diperoleh ditukarkan $\rightarrow$ Reinforcement atau penguatan.
Berhasilnya penerapan token ekonomi terhadap pola belajar anak selama pembelajaran daring di rumah, merupakan salah satu isyarat berhasilnya upaya dalam meningkatkan semangat belajar pada anak. Anak akan merasa lebih tertantang dan mengeluarkan segala upaya dalam mengumpulkan emotikon senyum atau bintang yang nantinya menjadi jaminan seberapa besar reward yang akan didapatkan oleh anak. Penelitian yang dilakukan oleh Parmawati, dkk (2015) membuktikan bahwa teknik ini dinilai efektif untuk meningkatkan kemampuan pemahaman anak tuna rungu dalam menguasai kosa kata baru. Dan dalam penelitian yang sama, Schunk (2008) dalam Santrock (2009) menyebutkan bahwa melalui token ekonomi, dapat menjadi sumber motivasi intrinsik anak untuk belajar karena memberikan informasi mengenai seberapa besar penguasaan anak terhadap tugas yang membuat perasaan kompetennya meningkat. Penelitian yang dilakukan oleh Lena (2019) yang dirilis oleh Jurnal Psikogenesis jugamenyatakan hal yang sama bahwa token ekonomi dinilai efektif dalam membentuk perilaku anak dalam meningkatkan durasi belajar pada waktu belajar di rumah. Dengan demikian, para guru dan orang tua tua tidak perlu lagi risau dalam meningatkan semangat belajar anak selama belajar daring di rumah 
karena token ekonomi memberikan solusi praktis yang sudah terbukti.

\section{Shaping}

Metode terakhir yang dapat digunakan dalam modifikasi perilaku pada anak selama diberlakukannya stay at home adalah melalui shaping. Shaping biasanya digunakan untuk megembangkan perilaku target yang belum ada pada diri individu. Menurut Miltenberger (2014), shaping didefinisikan sebagai penguatan diferensial dari pendekatan yang berurutan terhadap perilaku target sampai orang individu menunjukkan perilaku yang ingin dicapai. Penguatan diferensial melibatkan prinsipprinsip dasar reinforcement dan extinction. Penguatan diferensial terjadi ketika satu perilaku tertentu diperkuat dan semua perilaku lain tidak diperkuat dalam situasi tertentu. Akibatnya, perilaku yang diperkuat meningkat dan perilaku yang tidak dipaksakan menurun melalui extinction.

Dilansir pada CNN Indonesia menyebutkan bahwa anak lebih senang belajar di sekolah dibandingkan belajar di rumah. Karena di sekolah anak bisa berjumpa teman dan anak bisa menerima materi langsung dari guru tanpa ada perantara lain. Keluhan awal anak saat diberlakukannya stay at home adalah guru berbondong-bondong memberikan tugas kepada siswa. Sehingga membuat Komisi
Perlindungan Anak Indonesia (KPAI) mengeluarkan perintah bahwa baik guru maupun dosen tidak boleh memberikan tugas kepada siswa dan mahasiswa yang dapat memberatkan secara psikis. Banyak problema lain yang menjadi tantangan tersendiri dalam pola pemberlajaran selama pandemi ini.

Masa sekolah dasar merupakan masa dimana anak belajar untuk melatih diri dan berkreativitas seusianya. Tidak hanya guru kewarganegaraan dan matematika yang bingung dalam menjalankan prosedur pembelajaran daring, juga guru kesenian dan prakarya pun dibuat berpikir berkali-kali untuk memikirkan bagaimana cara yang efektif yang dapat digunakan dalam penyampaian materi. Karena mata pelajaran seni dan prakarya sebagian besarnya adalah praktek lapangan. Dengan aturan baru pemerintah yang menetapkan bahwa semua aktivitas lapangan ditiadakan dan dialihkan ke rumah, bukan berarti semua kreativitas anak juga harus dikarantina. Hanya karena pembelajaran dilakukan di rumah bukan berarti anak harus mengalami defisit dalam perilaku semangat belajar. Guru bisa saja memberikan tugas kepada siswa untuk berkreasi di rumah seperti belajar menanam tanaman sayur-sayuran yang nanti hasilnya bisa dinikmati oleh anak itu sendiri. 
Pertama, orang tua mendampingi anak dan mencontohkan secara penuh bagaimana cara dan tahapan yang benar dalam menanam daun bawang. Mulai dari menyiapkan cikal akar daun bawang yang akan ditanam, menyiapkan tanah dan pot plastik, serta kebutuhan lainnya yang dirasa perlu dalam proses penanaman daun bawang di lingkungan rumah. Setiap kali anak mampu mengikuti prosedur dan tahapan yang dicontohkan orang tua, maka orang tua perlu meberikan reinforcement (penguatan) berupa pujian atau senyuman sebagai isyarat bahwa anak sudah melakukan yang terbaik. Kedua, untuk hari selanjutnya orang tua bisa mendampingi anak dengan metode yang sama. Mungkin saja pada saat itu anak sudah bisa mengerjakan sebagian tanpa harus mendengarkan arahan dari orang tua dalam proses penanaman daun bawang. Kemudian, orang tua harus memberikan reinforcement (penguatan) kepada anak secara berkala jika anak menunjukkan perubahan perilaku dari awalnya yang tidak bisa mulai perlahan bisa. Karena kunci utama dari shaping adalah adanya penguatan pada setiap pencapain perilaku anak. Ketiga, tahapan selanjutnya adalah orang tua hanya perlu mengamati kegiatan anak dalam menanam daun bawang dari tahapan awal sampai akhir. Jika anak mampu mengerjakan semua prosedur tanpa bantuan orang tua, maka metode yang digunakan berhasil. Namun jika anak gagal, orang tua bisa menambah perpanjangan waktu dalam memberikan contoh dan bantuan atau mungkin orang tua bisa mengulang proses pertama sampai ketiga hingga anak berhasil mencapai perilaku target. Biasanya, anak akan lebih cenderung dan mudah menerapkan segala yang diajarkan dengan langsung praktek lapangan.

Tahapan pelaksanaan shaping: (1) Orang tua mendampingi anak + memberikan penjelasan + contoh $\rightarrow$ Anak berhasil $\rightarrow$ Pujian. (2) Orang tua mendampingi anak + tanpa penjelasan + sebagian contoh $\rightarrow$ Anak berhasil $\rightarrow$ Pujian. (3) Orang tua mendampingi + tanpa penjelasan + tanpa contoh $\rightarrow$ Anak berhasil $\rightarrow$ Pujian.

Menanam daun bawang hanya contoh sederhana dari sekian banyak kegiatan yang bisa dilakukan anak di rumah dalam berkreativitas dan berinovasi. Bisa dengan membuat kue bersama orang tua, belajar menanak nasi dengan magic com, atau kegiatan lainnya yang tidak membuat anak berpikir bahwa belajar di rumah adalah sesuatu yang membosankan. Semua tergantung bagaimana peran guru dan orang tua dalam meng-handle anak untuk tetap semangat menjalakan rutintas di rumah selama stay at home. Penelitian yang dilakukan oleh Ulandara \& Marlina (2018) menjelaskan bahwa teknik shaping 
tidak hanya efektif digunakan untuk anak berkebutuhan khusus, namun bisa diterapkan pada berbagai usia dan berbagai karakteristik anak yang berbeda-beda baik anak berkebutuhan khusus maupun tidak.

\section{KESIMPULAN}

Dengan diberlakukannya stay at home oleh pemerintah kepada seluruh jajaran di Indonesia membuat semua pihak mulai dari sektor perekonomian sampai pada sektor pendidikan memutar kepala bagaimana menjalankan rutinitas agar tetap efektif. Seperti yang dikatakan oleh UNESCO bahwa hamper 300 juta anak di dunia terganggu aktivitas sekolahnya dikarenakan wabah COVID-19 yang berkelana di sepanjang nadi dunia. Namun demikian, hal tersebut bukanlah menjadi alas an bagi para tenaga pendidik dan para siswa untuk lemah semangat dalam menuntut ilmu. Banyak kegitan dan aktivitas yang bisa dikerjakan selama stay at home. Terkhusus para guru dan orang tua, ada beberapa teknik modifikasi perilaku yang dapat dilakukan kepada anak dalam menjaga stabilitas dan meningkatkan semangat belajar anak selama pembelajaran daring di rumah. Misalnya fading yang menekankan pada pemberian bantuan kecil terhadap anak untuk mencapai perilaku target. Ada juga yang namanya token ekonomi, dimana guru diharapkan dapat memberikan penilaian kepada anak dengan menekankan pada proses dibandingkan hasil semata. Dan yang terakhir adalah shaping, dimana anak diajarkan dan diarahkan membentuk perilaku baru yaitu perilaku target dengan memberikan contoh pada awal dan pujian pada akhir. Keberhasilan dalam penggunaan ketiga teknik tersebut sangat dipengaruhi oleh peran orang guru dan khususnya pada orang tua di rumah. Teknik tersebut bisa saja gagal jika orang tua gagal menerapkan berdasarkan tahapan seharusnya. Maka dari itu, guru dan orang tua juga dituntut untuk berkontribusi besar dalam mempertahankan stabilitas dan meningkatkan semangat belajar anak selama stay at home.

\section{DAFTAR PUSTAKA}

Akmam, S. (2005). Panduan dan Strategi Motivasi Diri. Kuala Lumpur: Sanon Printing Corporation SDN BHD

Larassati, L. M., \& Hartiani, F. (2018). Penerapan Prompting dan Fading untuk Mengembangkan Tanggung Jawab Pada Anak Usia Sekolah. Jurnal Psikologi Teori dan Terapan, 8(2). 101-111. Mei 16, 2020

http://www.academia.edu/downloa d/56560661/3._Penerapan_Prompti ng_dan_Fading_untuk_Mengemba ngkan_Tanggung_Jawab.pdf

Lena, D. P. D. (2019). Efektivitas Teknik Antecedent Control dan Token Economy dalam Meningkatkan Durasi Perilaku Belajar pada Anak dengan Gangguan Intelektual Taraf 
Ringan. Jurnal Psikogenesis, 7(1),

84-95. Mei 16, 2020 http://academicjournal.yarsi.ac.id/in dex.php/Jurnal-Online-

Psikogenesis/article/view/880

Martin, G. \& Pear, J. (2015). Behavior Modification: What it is and how to do it (Tenth Edition). Pearson Education., USA

Miltenberger, R. G. (2014). Behavior Modification: Principles and Procedures. (Sixth Edition). Belmont: Wadsworth/Cengage Learning

Parmawati, S. B., dkk. (2015). Efektivitas Pendekatan Modifikasi Perilaku dengan Teknik Fading dan Token Economy dalam Meningkatkan Kosakata Siswa Tuna Rungu Prelingual Profound. Psibernetika, 8 (1), 19-34. Mei 14, 2020 https://pdfs.semanticscholar.org/5d 14/41f1c53c2ee971119f4c49760c9 965e14cb9.pdf
The McGraw-Hill Companies, Inc., USA

Sarafino. E. P. (2012). Applied Behavior Analysis : Principles and Procedures for Modifying Behavior. John Wiley \& Sons, Inc., USA

Ulandara, S., \& Marlina. (2018). Efektivitas Shaping-Token Economy dalam Meningkatkan Motivasi Belajar Anak Tunagrahita Ringan. Jurnal Penelitian Pendidikan Kebutuhan Khusus, 6(1), 150-155. Mei 14, 2020 http://ejournal.unp.ac.id/index.php/j upekhu/article/view/101651

Wardani, D. K. (2016). Psikologi Pendidikan Islam. Cirebon: CV. Confident.

Santrock, J. W. (2009). Educational Psychology (4th ed.). New York: 